ARTICLES

\title{
Do Entrepreneurs Make Predictable MisTAKES? EVIDENCE FROM CORPORATE DIVESTITURES
}

\author{
Peter G. Klein And SAndra K. Klein
}

fter a brief lull in the early 1990s, the market for corporate control
became increasingly active toward the end of the decade. Both 1996
and 1997 set new records for the number of U.S. merger filings, and 1998, 1999, and 2000 brought high-profile "mega-mergers" in financial services, energy, telecommunications, pharmaceuticals, and automobiles. In banking alone, for example, a wave of mergers over the last decade has led to widespread industry restructuring and consolidation. While total industry activity continues to expand, the number of U.S. banks and banking organizations both fell by almost 30 percent between 1988 and 1997 (Berger, Demsetz, and Strahan 1999).

Like other business practices that do not conform to textbook models of competition, mergers, acquisitions, and financial restructurings have long been viewed with suspicion by some commentators and regulatory authorities. However, the academic literature clearly suggests that corporate restructurings do, on average, create value. Event studies of acquisitions consistently find positive average combined returns to acquirer and target shareholders. As summarized by Jensen (1991, p. 15), "the most careful academic research

PETER G. KLEIN is assistant professor of economics, Terry College of Business, University of Georgia. SANDRA K. KLEIN is instructor of economics, Terry College of Business, University of Georgia. We are grateful to Randy Beard, John Chapman, Jerry Ellig, Nicolai Foss, Stavros Ioannides, Jennie Raymond, David Robinson, Ron Sanchez, and workshop participants at Auburn University, Copenhagen Business School, George Mason University, and the University of Georgia for helpful discussions, comments, and corrections.

THE QUARTERLY JOURNAL OF AUSTRIAN ECONOMICS VOL. 4, NO. 2 (SUMMER 2001): 3-23 
strongly suggests that takeovers-along with leveraged restructurings prompted by the threat of takeover-have generated large gains for shareholders and for the economy as a whole." These gains, historically about 8 percent of the combined value of the merging companies, "represent gains to economic efficiency, not redistribution between various parties" (Jensen 1988, p. 23). ${ }^{1}$

At the same time, however, several studies have found a sharp divergence between market participants' pre-merger expectations about the post-merger performance of merging firms and the firms' actual performance rates. Ravenscraft and Scherer's (1987) large-scale study of manufacturing firms, for example, found that while the share prices of merging firms did on average rise with the announcement of the proposed restructuring, post-merger profit rates were unimpressive. Indeed, they find that nearly one-third of all acquisitions during the 1960s and 1970s were eventually divested. Ravenscraft and Scherer conclude that acquisitions, particularly diversifying acquisitions, typically promote managerial "empire building" rather than efficiency. While acknowledging that product and capital markets eventually discipline poorly performing firms, forcing divestitures and other restructurings, Ravenscraft and Scherer (p. 217) argue for tighter government restrictions on mergers, particularly diversifying acquisitions and acquisitions financed by stock: "When the roads are strewn with wrecks, government officials cannot rest content because the tow trucks, ambulances, and hearses are doing a good job removing the remnants and clearing the right-of-way."2

Implicit in this criticism is the idea that divestitures of previously acquired assets expose past errors, and that these errors should have been foreseen (and perhaps prevented, if regulators had been sufficiently empowered). Certain types of acquisitions, it is claimed, are more likely to be later divested, so managers should generally avoid them. If such acquisitions occur, this is then cited as evidence for widespread agency problems. In this sense, the takeover wave of the 1980s is typically understood as an "undoing" of the earlier, conglomerate merger wave of the 1960s and early 1970s. According to conventional wisdom, the 1980 s was a period of respecialization or "refocus," showing the failures of unrelated diversification. The three decades from 1960 to 1990 thus represent a "round trip of the American corporation" (Shleifer and Vishny 1991, p. 54).

\footnotetext{
${ }^{1}$ On the gains from mergers, acquisitions, and other restructurings, see also the surveys by Jensen and Ruback (1983), Jarrell, Brickley, and Netter (1988), Roll (1988), Romano (1992), and Andrade, Mitchell, and Stafford (2001).

2Jensen (1986, 1993) argues similarly that diversifying acquisitions resulted from widespread agency problems in corporations, though he does not recommend any regulatory response: "The legal/political/regulatory system is far too blunt an instrument to handle the problems of wasteful managerial behavior effectively" (1993, p. 850). Instead, he advocates alternative forms of organization such as leveraged buyout associations and venture capital funds (see especially Jensen 1989).
} 
This view is based partly on evidence from studies of the conglomerate period by Rumelt (1974, 1982), Ravenscraft and Scherer (1987, 1991), Porter (1987), Kaplan and Weisbach (1992), and others who find no evidence that unrelated diversification brought long-term benefits to the firms that diversified. ${ }^{3}$ Combined with evidence of negative stock-market returns to diversification during the 1980s (Bhagat, Shleifer, and Vishny 1990; Lang and Stulz 1994; Berger and Ofek 1995; Comment and Jarrell 1995), many observers conclude that unrelated diversification is per se inefficient, and that the conglomerate era is best understood as an agency phenomenon.

The conventional wisdom on conglomerate sell-offs can be challenged on at least four grounds. First, divestitures of previously acquired assets do not necessarily show that the original acquisitions were failures. Weston (1989) argues that divestitures occur for a variety of reasons, such as changes in corporate strategies and antitrust rules, and not necessarily poor performance. Kaplan and Weisbach (1992) studied 217 large acquisitions completed between 1971 and 1982 and found that while 43.9 percent had been divested by 1989, only about a third of those divestitures were responses to poor post-merger performance. ${ }^{4}$ Thus the mere fact that many acquisitions are later divested does not prove widespread managerial misconduct.

Second, the market for corporate control is already highly regulated, and it is difficult to draw from current and recent experience strong conclusions about how unhampered capital markets would work. For example, Ravenscraft and Scherer (1987, 1991), Porter (1987), and other critics propose particular sequences of inefficient and efficient restructurings: diversifying, empire-building acquisitions in the 1960s and early 1970s, then efficient divestitures in the 1980s. But why did entrepreneurs make systematic mistakes during the conglomerate period, but not later? Can changes in the legal, political, and regulatory environments account for clusters of errors during specific periods?

Third, even if divestitures are seen as revealing prior mistakes, the failure of a particular acquisition does not necessarily indicate a failure of the underlying acquisition strategy. Certain kinds of acquisitions-for example, acquisitions of firms in knowledge-intensive, high-technology industries-may be

\footnotetext{
${ }^{3}$ Servaes (1996) also finds that conglomerate firms in the 1960s were valued at a discount relative to specialized firms. However, Matsusaka (1993) and Hubbard and Palia (1999) show that market participants rewarded conglomerate acquisitions during this period, and Klein (2001) offers valuation evidence consistent with the event-study results.

${ }^{4}$ Other empirical studies of asset sales and restructurings include Hite, Owens, and Rogers (1987); Lang, Poulsen, and Stulz (1994); John and Ofek (1995); and Schlingemann, Stulz, and Walkling (2000). These papers look at divestitures more generally, and not only at divestitures of previously acquired assets.
} 
inherently riskier than others. If the returns from a successful integration of the target's activities with the firm's existing activities are sufficiently high, then the acquisition has positive expected value, even if it is more likely to fail than a safer acquisition. Matsusaka (2001) offers this kind of interpretation of corporate diversification. Diversifying acquisitions represent experiments, as firms try various combinations of businesses, seeking those that match their capabilities (in the sense of Penrose 1959; Nelson and Winter 1982; and Wernerfelt 1984). After learning their capabilities, firms divest acquisitions that turn out to be poor matches. In this sense, divestitures reflect successful experiments -the acquirer has learned that the target's industry is not a good match for its capabilities. Such "match-seeking" firms will actively acquire and divest over time. ${ }^{5}$

This article elaborates a fourth, "Austrian" interpretation of corporate divestitures, one that builds on the three just mentioned. Austrian writers view market competition as a dynamic, rivalrous process that unfolds gradually through time-a "discovery procedure," in Hayek's (1978) famous phrase. The future holds genuine surprises, not merely a closed set of events whose probabilities are unknown. From this perspective, the long-term success of an acquisition, like any entrepreneurial action, cannot be "predicted." Entrepreneurs rely on judgment, or what Mises (1966) calls understanding. Understanding is intuitive, subjective, and qualitative, and thus inherently imperfect. For this reason, divestitures of underperforming subunits may be seen as efficient responses to unforeseen changes in industry and regulatory conditions, or more generally, to poor judgments by profit-seeking entrepreneurs. Ex post viability is not a good indicator of ex ante efficiency.

We begin with the theory of entrepreneurship proposed by Mises (1966), posing it as a challenge to the agency view of divestitures. We then present empirical evidence that the long-term performance of corporate acquisitions cannot, in general, be predicted by measures of agency conflicts. Instead, divestitures of previously acquired assets are more likely when firms are experimenting, learning, and otherwise trying to deal with uncertainty about

5Sanchez, Heene, and Thomas suggest that the same is true for networks and alliances.

In a dynamic market context, longevity of interfirm alliances is not necessarily an indicator of successful collaboration. A succession of short-term alliances by a firm, for example, may suggest that the firm has a superior ability to learn from its partners, or that it may have superior ability to quickly reconfigure its chain of firm-addressable resources in response to changing competitive and market conditions. (1966, p. 28)

Mosakowski (1997) also offers an experimentation theory of diversification (without looking at subsequent divestitures). 
future conditions. We also show that mistaken acquisitions are more likely under certain circumstances, namely during periods of intense, industry-specific regulatory activity. Our own research on restructuring (Klein and Klein 2001) shows that significantly higher rates of divestiture follow mergers that occur in a cluster of mergers in the same industry. As argued by Mitchell and Mulherin (1996), Andrade and Stafford (1999), and Andrade, Mitchell, and Stafford (2001), mergers frequently occur in industry clusters, suggesting that mergers are driven in part by industry-specific factors, such as regulatory shocks. When an industry is regulated, deregulated, or re-regulated, economic calculation becomes more difficult, and entrepreneurial activity is hampered. It should not be surprising that poor long-term performance is more likely under those conditions.

This last result is consistent with the view, expressed repeatedly in the Austrian literature, that entrepreneurial error is associated with government intervention in the marketplace-in particular, with government ownership of property and interference with the price system. Mises (1990) famously showed that economic calculation is not possible without private property in all markets, especially markets for factors of production. The Austrian business-cycle literature (Mises 1934; Hayek 1935; Garrison 2001) suggests that entrepreneurial errors are more likely under governmentsponsored credit expansion. This article makes a related argument: Entrepreneurial decisions to make acquisitions that will later be regretted, and divested, are more likely in the wake of government intervention in particular industries.

The remainder of the article is organized as follows. The first section reviews the Austrian literature on entrepreneurship, uncertainty, and economic calculation, suggesting that the ex post success of entrepreneurial actions cannot be forecasted based on generally available information. The second section introduces recent theory and evidence on the reasons for mergers and divestitures, contrasting two opposing views of sell-offs: empire-building and experimentation. The third section reviews some empirical evidence on the pre-merger causes of divestiture, challenging the generally accepted, empire-building explanation. The final section concludes.

\section{ENTREPRENEURSHIP, PROFIT, AND LOSS}

Entrepreneurship, as Mises (1966) conceives it, is the act of bearing uncertainty. Production takes time, so entrepreneurs must purchase factors of production in the present (paying today's prices, which are known), in anticipation of revenues from the future sale of the product (at tomorrow's prices, which are uncertain). Entrepreneurial profit or loss is the difference between these revenues and the initial outlays, less the general rate of interest. As such, 
profit is the reward for successfully bearing uncertainty. Successful entrepreneurs, or "promoters" in Mises's terminology, are those who make accurate forecasts of future prices and receive returns greater than their outlays. Those whose forecasts are less accurate earn losses. Promoters who consistently make poor forecasts quickly find themselves unable to secure any further resources for investment and eventually exit the market.

This entrepreneur-promoter is absent from textbook models of competitive general equilibrium in which uncertainty is defined away, replaced by probabilistic risk. In these models it is possible to anticipate which actions, on average, would be profitable. In a world of "true" (structural, rather than parametric) uncertainty, however, profit opportunities do not exist "out there," waiting to be realized by anyone willing to take a specified action. Instead, profit opportunities are created through entrepreneurial action. As emphasized in one strand of modern Austrian literature, entrepreneurial skill is not simply luck or "alertness," the ability to recognize profit opportunities that appear, ex nihilo, to the discoverer. Rather, entrepreneurship is judgment: "Alertness is the mental quality of being on the lookout for something new; judgment is the mental process of assigning relevance to those things we already know" (High 1982, p. 167). In this context,

promoter-entrepreneurs are those who seek to profit by actively promoting adjustment to change. They are not content to passively adjust their . . . activities to readily foreseeable changes or changes that have already occurred in their circumstances; rather, they regard change itself as an opportunity to meliorate their own conditions and aggressively attempt to anticipate and exploit it. (Salerno 1993, p. 123; see also Hülsmann 1997)

All entrepreneurs, particularly those who operate in financial markets, use economic calculation as their primary decision-making tool. ${ }^{6}$ By economic calculation, Mises means simply the use of present prices and anticipated future prices to compare present costs with expected future benefits. In this way the entrepreneur decides what goods and services should be produced, and what methods of production should be used to produce them.

The business of the entrepreneur is not merely to experiment with new technological methods, but to select from the multitude of technologically feasible methods those which are best fit to supply the public in the cheapest way with the things they are asking for most urgently. (Mises 1980, p. 110)

To make this selection, the entrepreneur must weigh the costs and expected benefits of various courses of action, and for this he needs the cardinal numbers

${ }^{6}$ Klein (1999) argues that financial-market entrepreneurship is a particularly important form of entrepreneurial activity, though it has received little attention in the Austrian literature. 
provided by money prices. Monetary calculation, then, requires private property and market prices (Mises 1966, p. 229).

Mises's famous 1920 essay on economic calculation under socialism is not so much about socialism per se; it is an argument about the role of prices for capital goods (Rothbard 1993, pp. 547-78; Klein 1996). Entrepreneurs make decisions about resource allocation based on their expectations about future prices and the information contained in present prices. To make profits, they need information about all prices, not only the prices of consumer goods but the prices of factors of production. Without markets for capital goods, these goods can have no prices, and therefore entrepreneurs cannot make judgments about the relative scarcities of these factors. In short, resources cannot be allocated efficiently. In any environment, then-socialist or not-where a factor of production has no market price, a potential user of that factor will be unable to make rational decisions about its use. Stated this way, Mises's claim is simply that efficient resource allocation in a market economy requires wellfunctioning asset markets.

Despite Mises's explicit focus on entrepreneurship, much of modern production theory-indeed, the entire neoclassical theory of the firm-focuses not on entrepreneurs, but managers. The traditional theory of profit maximization is nearly always told from the perspective of the manager, the agent who operates the plant, not that of the owner, who supplies the capital to fund the plant. Yet owners control how much authority to delegate to operational managers, so capitalists are, in an important sense, the ultimate decision makers. To understand the firm, then, we must focus on the actions and plans of the suppliers of financial capital, the capitalist-entrepreneurs.

It is true, of course, that when capitalist-entrepreneurs supply resources to firms, they usually delegate to managers the day-to-day responsibility for use of those resources. The resulting possibility for managerial discretion is of course the focal problem of the modern literature on corporate finance and the theory of the firm. The literature on corporate governance identifies a variety of mechanisms by which shareholders can limit this discretion. Internally, owners may establish a board of directors to oversee the actions of managers. They can use performance-based compensation to motivate managers to act in the owners' interests. They can adopt a particular organizational form, such as the "M-form" structure, in which managerial discretion is more easily kept in check (Williamson 1975). Finally, they can rely on competition within the market for managers to limit the discretionary behavior of top-level management (Fama 1980).

Even more important are external forces that help align managers' interests with those of shareholders. ${ }^{7}$ Competition in the product market, for

\footnotetext{
7 Jensen (1993) argues that internal control mechanisms are generally weak and ineffective, while external control mechanisms-where allowed to function-are typically superior.
} 
example, assures that firms whose managers engage in too much discretionary behavior will fail, costing the managers their jobs. In countries where universal banking is permitted, large equity holders such as banks can exercise considerable influence over managerial behavior. The external governance mechanism that has received the most attention, of course, is the market for ownership itself, the market for corporate control. Anticipating Manne (1965), Mises (1966) makes the general point that financial markets play a vital disciplinary role:

[T] he changes in the prices of common and preferred stock and of corporate bonds are the means applied by the capitalists for the supreme control of the flow of capital. The price structure as determined by the speculations on the capital and money markets and on the big commodity exchanges not only decides how much capital is available for the conduct of each corporation's business; it creates a state of affairs to which the managers must adjust their operations in detail. (p. 303)

The market for corporate control thus places strict limits on the ability of managers to pursue their own goals rather than those of the capitalist-entrepreneurs.

The Austrian view of the entrepreneurial market process sheds light on the debate over the effectiveness of the takeover mechanism in providing managerial discipline. A common concern is the belief that financial markets produce too few disciplinary takeovers, due to a free-rider problem associated with tender offers (Scharfstein 1988). Critics point out that if the difference between the current (undervalued) price of the firm and its aftertakeover market value is common knowledge, then the target firm's shareholders will refuse to tender their shares until the current price is bid up, appropriating a share of the returns to the acquiring firm. These critics conclude that regulation, not the takeover market, should be used to discipline managers.

The flaw in this argument is that it assumes perfect knowledge by investors. The typical shareholder will not usually have the same information as incumbent managers, outside "raiders," and other specialists. It is not in the small shareholder's interest to learn these details; that is why he delegates such responsibilities to the managers in the first place. As Hayek (1945) described it, there is a "division of knowledge" in society. The raider who discovers a difference between a firm's current market value and its potential value under new management has an opportunity for an entrepreneurial profit (less the transaction costs of takeover). Because shareholders have delegated these responsibilities, they will not usually earn a share of this profit. Moreover, the post-takeover market value of the firm is uncertain; the raider's profit, if he is successful, is the reward for bearing this uncertainty. In this sense the takeover artist is a Misesian capitalist-entrepreneur. Successful takeover specialists earn pure entrepreneurial profit; the rest suffer entrepreneurial loss. Raiders thus 
have powerful incentives to undertake disciplinary restructurings, and this places strict limits on managerial discretion.

We should therefore be cautious in attributing the eventual divestiture of many acquisitions, particularly during the 1960s and 1970s, to managerial motives. Moreover, the claim that the acquisitive conglomerates of the 1960s and 1970s were inefficient is inconsistent with recent evidence that during those years, diversifying acquisitions-particularly those that created internal capital markets-tended to increase the market values of the acquiring firms (Matsusaka 1993; Hubbard and Palia 1999; Klein 2001). In light of this evidence, "[t]he simple view that the 1980s 'bust-ups' were a corrective to past managerial excesses is untenable" (Matsusaka 1993, p. 376). In short, both theory and empirical evidence cast doubt on the conventional wisdom that corporate managers made systematic, predictable mistakes by acquiring (often unrelated) subunits during the 1960s and 1970s, and that financial-market participants made systematic mistakes by approving these acquisitions.

\section{Mergers, Sell-offs, And Efficiency: Theory and Evidence}

Why, in general, do firms expand and diversify through merger? Why do they sometimes retreat and "refocus" through divestiture? The theory of merger is a subset of the theory of the optimal size and shape of the firm, a relatively undeveloped area in the Austrian literature. Klein (1996) argues for a modified Coasian, or contractual, view of firm boundaries, in which the limits to organization are given by the need to perform economic calculation using prices generated in external markets. Other writers see the Austrian approach as more congenial to the resource-based theory of the firm, defining firms' capabilities in terms of Hayekian tacit knowledge (Langlois 1992, 1994; Minkler 1993). In either case, we can think of merger or takeover as a response to a valuation discrepancy: Acquisition occurs when the value of an existing firm's assets is greater to an outside party than to its current owners. Put differently, merger can be a response to economies of scope, in that the value of the merging firms' assets combined exceeds their joint values separately. ${ }^{8}$ As

\footnotetext{
${ }^{8}$ Two popular explanations for multiproduct economies of scope center on internal capital markets and strategic resources. According to the internal-capital-markets hypothesis, as expressed by Alchian (1969); Williamson (1975); Gertner, Scharfstein, and Stein (1994); and Stein (1997), internal capital markets have advantages where access to external funds is limited. The central office of the diversified firm can use informational advantages, residual control rights, and its ability to intervene selectively in divisional affairs to allocate resources within the firm better than the external capital markets would do if the divisions were stand-alone firms. In the resource-based view, the firm is regarded as a stock of knowledge, establishing a range of competence that may extend across multiple product lines. Excess profits or supranormal returns are seen as rents accruing to unique factors of production (Montgomery and Wernerfelt 1988) and firms diversify because they have excess capacity in these unique factors.
} 
with any voluntary exchange, the transaction is (ex ante) advantageous to both parties, and should thus be welfare-enhancing.

New combinations of corporate assets can generate efficiencies by replacing poorly performing managers ( Jensen and Ruback 1983; Mitchell and Lehn 1990), creating operating synergies (Weston, Chung, and Hoag 1990, pp. 194-95), or establishing internal capital markets (Alchian 1969; Williamson 1975; Gertner, Scharfstein, and Stein 1994; Stein 1997). In particular, considerable evidence suggests that the market for corporate control disciplines incumbent management. For example, Morck, Shleifer, and Vishny (1988) found that firms with lower Tobin's q-ratios are more likely to be targets of takeovers. Tobin's q measures the ratio of the firm's market value to the replacement cost (or book value) of its assets. Because firms with low marketto-book ratios have low expected cash flows relative to the amount of invested capital, the market-to-book ratio can be interpreted as a measure of the firm's investment opportunities (Smith and Watts 1992; Gaver and Gaver 1993), or as a measure of managerial inefficiency or agency conflict within the firm (Lang, Stulz, and Walkling 1991). Low-q firms are the most likely takeover targets.

Given the benefits of takeovers, why are many mergers later "reversed" in a divestiture or spin-off? Here we distinguish between two basic views. The first, which may be termed empire-building, holds that entrenched managers make acquisitions, often paying with the acquiring firm's (inflated) stock, primarily to increase their own power, prestige or control. These acquisitions produce negligible efficiency gains, and are thus more likely to be divested ex post. Most important, because the acquiring firm's motives are suspect, such acquisitions are ex ante inefficient; neutral observers can predict, based on pre-merger characteristics, that these mergers are unlikely to be viable over time. By permitting these acquisitions, capital-market participants are also guilty of systematic error. Admittedly, in the empire-building view, markets did eventually correct these mistakes with the restructurings of the 1980s. ${ }^{9}$ Still, farsighted regulators could have reduced social costs by limiting such acquisitions in the first place.

A second view, which we term entrepreneurial market process, acknowledges that unprofitable acquisitions may be mistakes ex post, but argues that

\footnotetext{
${ }^{9}$ This raises the question of why, if managers were sufficiently entrenched to make inefficient acquisitions in the first place, would they not remain sufficiently entrenched to hold on to poorly performing targets, rather than divest them and risk revealing their underlying objectives? Boot (1992, p. 1402) argues that an entrenched manager will not divest because the external market will take divestiture as an admission of failure and a bad signal of his ability. The argument that divestitures indicate agency problems thus assumes a change in corporate control between the original acquisitions and the later divestitures.
} 
poor long-term performance does not indicate ex ante inefficiency. In the market-process perspective, a divestiture of previously acquired assets may mean simply that profit-seeking entrepreneurs have updated their forecasts of future conditions or otherwise learned from experience. As Mises (1966, p. 252) puts it, "the outcome of action is always uncertain. Action is always speculation." Consequently,

the real entrepreneur is a speculator, a man eager to utilize his opinion about the future structure of the market for business operations promising profits. This specific anticipative understanding of the conditions of the uncertain future defies any rules and systematization. (p. 585, emphasis added $)^{10}$

As discussed above, this notion of entrepreneurial decision-making under uncertainty squares with recent theories of acquisitions as a form of experimentation (Mosakowski 1997; Boot, Milbourn, and Thakor 1999; Matsusaka 2001). In these models, profit-seeking entrepreneurs can learn their own capabilities only by trying various combinations of activities, which could include diversifying into new industries. Firms may thus make diversifying acquisitions even if they know these acquisitions are likely to be reversed in a divestiture. This process generates information that is useful for revising entrepreneurial plans, and thus an acquisition strategy may be successful even if individual acquisitions are not. In these cases, the long-term viability of an acquisition may be systematically related to publicly observable, premerger characteristics associated with experimentation, but not characteristics associated with managerial discretion.

To explain the particular pattern of mergers and acquisitions observed, over the last several decades, market-process explanations must appeal to changes in the legal, political, competitive, or regulatory environments that affect the ability of entrepreneurs to anticipate future conditions. Why, for instance, was it particularly difficult for entrepreneurs to forecast the success of acquisitions in the 1960s and 1970s? Why did entrepreneurs feel a greater need to experiment with various combinations of businesses during those years?

One possibility is that complex organizations with active internal capital markets were necessary in the 1960s, but became less important after capital markets were deregulated in the 1970s. The investment community in the 1960s has been described as a small, close-knit group where competition was minimal and peer influence strong (Bernstein 1992). As Bhide (1990, p. 76)

\footnotetext{
10Mises (1949, pp. 110-15) replaces Knight's (1921) distinction between risk and uncertainty with that between "class probability," in which members of a class of events share certain characteristics, and "case probability" in which each event is a unique case.
} 
puts it, "internal capital markets . . may well have possessed a significant edge because the external markets were not highly developed. In those days, one's success on Wall Street reportedly depended far more on personal connections than analytical prowess." During that period, the financial markets were relatively poor sources of capital. In 1975, the SEC deregulated brokerage houses and removed its rule on fixed-price commissions. The effect of deregulation, not surprisingly, was to increase competition among providers of investment services. "This competitive process has resulted in a significant increase in the ability of our external capital markets to monitor corporate performance and allocate resources" (p. 77). As the cost of external finance has fallen, firms have tended to rely less on internal finance, and thus the value added from internal-capital-market allocation has fallen. Consequently, firms have adopted simpler, more "focused" structures that rely more heavily on external capital markets and outsourcing, possibly explaining some of the divestitures observed in the last two decades.

\section{Are Divestitures Predictable? Evidence From a Duration Study}

This section summarizes our own research (Klein and Klein 2001) on the causes of divestiture. If acquisitions are most often symptoms of managerial empire-building, as suggested by Ravenscraft and Scherer (1987), Porter (1987), and other critics, then pre-merger characteristics associated with high levels of managerial discretion should be systematically related to the long-term failure and reversal of these acquisitions. In the market-process view, by contrast, long-term performance should be correlated only with premerger characteristics associated with experimentation, rapidly changing environments, or knowledge-intensive industries. Our empirical research finds little support for the empire-building hypothesis, and much stronger support for the market-process view. Specifically, we find that most characteristics typically associated with empire-building are poor predictors of merger duration. The evidence also suggests that divestiture is more likely when the original acquisition is driven by industry-specific competitive or regulatory shocks.

We studied 222 pairs of firms that merged during the 1977-1983 period. Of the 222 acquisitions, 64, or almost 30 percent, had been divested by July 1995. We used a duration or "hazard" model to study the effects of pre-merger characteristics on the time to divestiture. Duration models help explain how exogenous factors, unobserved factors, and time itself affect the average duration until some discrete event (in our case, divestiture) occurs. Duration analysis allows us to see, historically, how characteristics of the acquiring and acquired firms affect the likelihood that the acquired firm will later be divested. 
To study the effects of pre-merger characteristics on average merger duration, we estimated a hazard regression of duration (measured as the natural logarithm of the number of days) on a constant and on a series of potentially exogenous factors. For assessing the empire-building hypothesis, we included three characteristics associated with high levels of managerial discretion: relatedness of target and acquirer, differences in price-earnings ratios, and the medium of payment. Relatedness addresses the common view that managers deliberately pursue unrelated targets to expand their control or make themselves more valuable to the firm. Following Kaplan and Weisbach (1992), we examined this claim by constructing a dummy variable equal to one if the acquiring and target firm share at least one two-digit SIC code and zero otherwise.

Differences in price-earnings ratios are commonly seen as another indicator of merger motives. Merger critics have often suggested that acquiring firms grow and prosper by "bootstrapping." This refers to the practice whereby bidding firms seek targets with low $\mathrm{P} / \mathrm{E}$ ratios to boost their reported earnings per share. It is trivially mathematically true that when a firm with a high $\mathrm{P} / \mathrm{E}$ multiple acquires a firm with a low $\mathrm{P} / \mathrm{E}$ multiple and pays with its own stock, the acquirer's earnings per share will rise, simply because the combined earnings of the two firms will then be divided by a smaller number of total shares outstanding. Hence, it is argued, acquiring firms can expand rapidly, with market approval, as managers exploit this accounting opportunity. ${ }^{11}$

Of course, this argument assumes market participants could be systematically fooled by a simple algebraic trick. Admittedly, much more complicated financial and balance-sheet manipulations are often used in corporate-control transactions: bidders in the 1960s and 1970s sometimes financed acquisitions with convertible bonds, convertible preferred stocks, and other unique instruments. Although investors could (and eventually did) require that earnings be reported on a "fully diluted" basis, to take account of these manipulations, Malkiel (1990, p. 61) reports that "most investors in the middle 1960s ignored such niceties and were satisfied only to see steadily and rapidly rising earnings." However, there is no evidence that bootstrapping was either prevalent or successful (Barber, Palmer, and Wallace 1995; Matsusaka 1993).

11This is Malkiel's (1990) explanation for the conglomerate boom:

[T] he major impetus for the conglomerate wave of the 1960s was that the acquisition process itself could be made to produce growth in earnings per share. .. . By an easy bit of legerdemain, [conglomerate managers] could put together a group of companies with no basic potential at all and produce steadily rising per-share earnings. (p. 58) $55-56)$.

For a more balanced discussion of the bootstrapping practice see Lynch (1971, pp. 
Nonetheless, we included a measure of relative $\mathrm{P} / \mathrm{E}$ ratios to see if acquirers that choose targets with lower $\mathrm{P} / \mathrm{E}$ ratios are historically more likely to divest those same targets, implying that bootstrapping does tend to fool investors, as increases in reported earnings disguise inefficient acquisitions.

We also included a series of dummy variables to represent the medium of payment used in the merger. Several theories suggest that how an acquisition is financed can affect performance. First, the bootstrapping technique described above works only for mergers financed by stock swap. Second, Jensen (1986) holds that financing takeovers by issuing debt serves to discipline the acquiring firm's management by reducing post-merger discretion in the use of free cash flow. If true, we would expect entrenched managers to avoid making acquisitions using debt, opting for stock swaps instead.

In the market-process or experimentation view, by contrast, divestitures occur when the acquirer receives new information about the target after the merger has taken place. Plausibly, some relevant characteristics of potential target firms can be learned only by experience, forcing entrepreneurs to revise their plans accordingly. What kinds of targets are most likely to have unknown characteristics? Large firms engage in more activities than smaller firms, so potential acquirers have more to learn. On the other hand, smaller firms are less likely to have been written about in the business press, so one could plausibly argue that private information is a bigger problem for small targets. ${ }^{12}$ We include target size in our regressions to see if either aspect is relevant. Firms in rapidly changing, knowledge-intensive industries are also likely to have characteristics hidden from potential acquirers. To capture this effect, we created a dummy variable based on two-digit SIC codes. The dummy takes a value of one if the target is in any of the following industries: computers (systems, software, and services), medical products, communications, aerospace, and miscellaneous high-tech industries. We also included target R\&D because $R \& D$ is difficult to value, especially to outsiders, and thus firms in R\&Dintensive industries are likely to have hidden characteristics. Potential acquirers would know potential targets' R\&D expenditures (which is reported), but this may not give the acquirers much information on the quality of the research or even the content of the R\&D.

Finally, unrelated acquisitions, as discussed above, may be a form of experimentation, as firms try new combinations of activities to find those that best fit their existing capabilities. Although match-seeking acquisitions are more likely to be divested they can still be part of a value-maximizing acquisition strategy. Our relatedness variable, described above, can proxy for match-seeking behavior. However, the best way to identify match-seeking

${ }^{12}$ However, in our sample, all targets are themselves publicly traded corporations, so lack of media exposure is unlikely to be a problem. 
firms is to look directly at historical patterns of acquisitions and divestitures. A firm with a history of repeated acquisitions and divestitures, especially acquisitions into unrelated industries, is likely to be a match-seeker, and thus any current acquisition is more likely to be divested. Unfortunately, our merger sample is too small to compile detailed acquisition and divestiture histories on individual acquirers. As a first approximation, we searched our sample for acquiring firms with at least one previous acquisition that was later divested within a few years of the acquisition. We created a dummy variable equal to one if the acquirer in a particular merger met these criteria, and zero otherwise. 13

As noted above, periods of intense merger activity in particular industries may be responses to industry-specific competitive or regulatory shocks. Mitchell and Mulherin (1996), Andrade and Stafford (1999), and Andrade, Mitchell, and Stafford (2001) argue that mergers tend to occur in industry clusters, suggesting that industry-specific factors are important. Mitchell and Mulherin argue that corporate takeovers are often the most cost-effective way for industries to respond to these shocks. Moreover, they add, "because takeovers are driven in part by industry shocks, it is not surprising that many firms exhibit volatile performance following takeovers, with actual failures following some negative shocks" (Mitchell and Mulherin 1996, p. 195).

To capture the effects of industry-specific shocks such as regulatory and tax changes, we included measures of industry clustering, both for acquirers and for targets, in our regressions. We did find substantial clustering in our sample. For example, slightly more than half of the mergers during 1977-1983 period occurred in only five of the thirty-seven (two-digit) SIC industries in our sample, both for acquirers and targets, with three-quarters occurring in ten industries. We constructed clustering variables by counting the number of mergers in each two-digit SIC category in each year and creating variables for each merger corresponding to the number of mergers occurring (a) within one year of the merger under observation (including the year before the merger, the year of the merger, and the year after the merger, to span a three-year window), (b) within two years of the merger (a five-year window), and (c) within the entire sample (a seven-year window). If risky acquisitions or increased levels of experimentation tend to appear during periods of industry-specific shocks, then these clustering variables will have negative and significant effects on the length of time to divestiture.

Our results challenge the empire-building hypothesis and offer evidence more consistent with the market-process view. Of the variables associated with

${ }^{13}$ Mosakowski (1997) suggests that younger firms face greater uncertainty, or a higher level of "causal ambiguity," about the best use of their resources, which implies that firm age could also be a proxy for match-seeking behavior. 
agency problems, only relatedness has a statistically significant effect on merger duration. Neither P/E differences nor the medium of payment has a statistically significant coefficient in any of several specifications. The coefficient on relatedness is positive, meaning that related acquisitions are less likely, on average, to be divested (as in Kaplan and Weisbach 1992). However, the coefficient on relatedness is also consistent with the market-process explanation. Of the five variables associated with this view, the coefficient on relatedness is positive and significant, the coefficient on target $R \& D$ is negative and significant, and the coefficient on the match-seeking indicator is negative and significant, all as expected. The coefficients on target size and the indicator for high-technology industries have the expected signs (positive and negative, respectively) but are not statistically significant.

Overall, our findings suggest that the divestitures in our sample are not, on average, the predictable result of unwise acquisitions. Rather, divestitures follow experimentation and learning, healthy characteristics of a market economy. Moreover, industry clustering appears to have a regular effect on average merger duration. The coefficients on our acquirer-clustering variables are consistently negative and statistically significant. (The coefficients on the targetclustering variables, by contrast, are not statistically significant.) This suggests that volatile performance does follow shocks, as suggested by Mitchell and Mulherin (1996).

This finding is consistent with the view that firms make acquisitions when faced with increased uncertainty (see Spulber 1992, pp. 557-59). Regulatory interference could be a major cause of such uncertainty. As discussed above, government intervention makes economic calculation more difficult, and can ultimately render calculation impossible. When faced with increased regulatory interference, firms apparently respond by experimenting, making riskier acquisitions, and consequently making more mistakes, ex post.

\section{CONCLUSIONS}

Do entrepreneurs make predictable mistakes? Theory and evidence suggest otherwise. Contrary to the conventional wisdom on mergers and sell-offs, divestitures of previously acquired assets do not necessarily indicate that the original acquisitions were mistakes. Indeed, empire-building motives do not seem to be systematically related to long-term merger performance. Instead, divestitures are more likely to be associated with experimentation, learning, and other socially beneficial activities.

Acquisitions are uncertain endeavors, and the entrepreneur-promoteralong with the manager to whom he delegates authority-is a speculator. If the consequences of his actions were determinate, he would not be an entrepreneur, but rather, as some economic theories seem to treat him, "a soulless 
automaton" (Mises 1966, p. 585). However, the future can never be known with certainty; long-term profit and loss cannot be predicted based on current information. As Mises explains:

What distinguishes the successful entrepreneur and promoter from other people is precisely the fact that he does not let himself be guided by what was and is, but arranges his affairs on the ground of his opinion about the future. He sees the past and the present as other people do; but he judges the future in a different way. (p. 585)

As discussed above, it is hardly surprising that these judgments are less than perfect. The relevant question for policy is whether there is a feasible alternative to market-based corporate governance. Our reading of the political-economy literature leaves us doubtful that such an alternative exists.

\section{REFERENCES}

Alchian, Armen A. 1969. "Corporate Management and Property Rights." In Economic Policy and the Regulation of Corporate Securities. Henry Manne, ed. Washington, D.C.: American Enterprise Institute. Pp. 337-60.

Andrade, Gregor, and Erik Stafford. 1999. "Investigating the Economic Role of Mergers." Working paper, Harvard Business School.

Andrade, Gregor, Mark Mitchell, and Erik Stafford. 2001. "New Evidence and Perspectives on Mergers." Journal of Economic Perspectives 15 (Spring): 103-20.

Barber, Brad M., Donald Palmer, and James Wallace. 1995. "Determinants of Conglomerate and Predatory Acquisitions: Evidence from the 1960s." Journal of Corporate Finance: Contracting, Governance and Organization 1 (April): 283-318.

Berger, Allen N., Rebecca S. Demsetz, and Philip E. Strahan. 1999. "The Consolidation of the Financial Services Industry: Causes, Consequences, and Implications for the Future." Journal of Banking and Finance 23 (February): 135-94.

Berger, Philip G., and Eli Ofek. 1995. "Diversification's Effect on Firm Value.” Journal of Financial Economics 37 (January): 39-65.

Bernstein, Peter L. 1992. Capital Ideas: The Improbable Origins of Modern Wall Street. New York: Free Press.

Bhagat, Sanjai, Andrei Shleifer, and Robert W. Vishny. 1990. "Hostile Takeovers in the 1980s: The Return to Corporate Specialization." Brookings Papers on Economic Activity: Microeconomics. Pp. 1-72.

Bhide, Amar. 1990. "Reversing Corporate Diversification." Journal of Applied Corporate Finance 3 (Summer): 70-81.

Boot, Arnoud W.A. 1992. "Why Hang on to Losers? Divestitures and Takeovers." Journal of Finance 48(4): 1401-23. 
Boot, Arnoud W. A., Todd T. Milbourn, and Anjan V. Thakor. 1999. "Megamergers and Expanded Scope: Theories of Bank Size and Activity Diversity." Journal of Banking and Finance 23: 195-214.

Comment, Robert, and Gregg A. Jarrell. 1995. "Corporate Focus and Stock Returns." Journal of Financial Economics 37 (January): 67-87.

Fama, Eugene F. 1980. "Agency Problems and the Theory of the Firm." Journal of Political Economy 88:288-307.

Garrison, Roger W. 2001. Time and Money: The Macroeconomics of Capital Structure. London: Routledge.

Gaver, Jennifer J., and Kenneth M. Gaver. 1993. "Additional Evidence on the Association Between the Investment Opportunity Set and Corporate Financing, Dividend, and Compensation Policies." Journal of Accounting and Economics 16: $125-60$.

Gertner, Robert H, David S. Scharfstein, and Jeremy C. Stein. 1994. "Internal Versus External Capital Markets." Quarterly Journal of Economics 109:1211-30.

Hayek, F. A. [1931] 1935. Prices and Production. 2nd Rev. Ed. London: Routledge and Kegan Paul.

_ 1945. "The Use of Knowledge in Society." In Individualism and Economic Order. London: Routledge and Kegan Paul. Pp. 77-91.

—. [1968] 1978. "Competition as a Discovery Procedure." In New Studies in Philosophy, Politics and Economics. Chicago: University of Chicago Press. Pp. $179-90$.

High, Jack. 1982. "Alertness and Judgment: Comment on Kirzner." In Method, Process, and Austrian Economics: Essays in Honor of Ludwig von Mises. Israel M. Kirzner, ed. Lexington, Mass.: D.C. Heath. Pp. 161-68.

Hite, Gailen L., James E. Owens, and Ronald C. Rogers. 1987. "The Market for Interfirm Asset Sales: Partial Sell-offs and Total Liquidations." Journal of Financial Economics 18:229-52.

Hubbard, R. Glenn, and Darius A. Palia. 1999. "A Reexamination of the Conglomerate Merger Wave in the 1960s: An Internal Capital Markets View." Journal of Finance 54:1131-52.

Hülsmann, Jörg Guido. 1997. "Knowledge, Judgment, and the Use of Property." Review of Austrian Economics 10(1): 23-48.

Jensen, Michael C. 1986. "Agency Costs of Free Cash Flow, Corporate Finance and Takeovers.” American Economic Review 76:323-29.

—. 1989. "Eclipse of the Public Corporation." Harvard Business Review (September-October).

—. 1991. "Corporate Control and the Politics of Finance." Journal of Applied Corporate Finance 6:13-33.

—. 1993. "The Modern Industrial Revolution, Exit, and the Failure of Internal Control Systems." Journal of Finance 48 (July): 831-80. 
Jensen, Michael C., and Richard S. Ruback. 1983. "The Market for Corporate Control: The Scientific Evidence." Journal of Financial Economics 11 (April): 5-50.

John, Kose, and Eli Ofek. 1995. "Asset Sales and Increase in Focus." Journal of Financial Economics 37:105-26.

Kaplan, Steven N., and Michael S. Weisbach. 1992. "The Success of Acquisitions: Evidence from Divestitures." Journal of Finance 47 (March): 107-38.

Klein, Peter G. 1996. "Economic Calculation and the Limits of Organization." Review of Austrian Economics 9(2): 51-77.

- 1999. "Entrepreneurship and Corporate Governance." Quarterly Journal of Austrian Economics 2(2): 19-42.

—. 2001. "Were the Acquisitive Conglomerates Inefficient?" Working paper, Department of Economics, University of Georgia.

Klein, Peter G., and Sandra K. Klein. 2001. "Are Divestitures Predictable? A Duration Analysis." Working paper, Department of Economics, University of Georgia.

Knight, Frank H. 1921. Risk, Uncertainty, and Profit. New York: Hart, Schaffner and Marx.

Lang, Larry H. P., Annette B. Poulsen, and René M. Stulz. 1994. "Firm Performance, Asset Sales, and the Costs of Managerial Discretion." Journal of Financial Economics 37:3-37.

Lang, Larry H. P., and René M. Stulz. 1994. "Tobin's Q, Corporate Diversification, and Firm Performance." Journal of Political Economy 102 (December): 1248-80.

Lang, Larry H. P., René M. Stulz, and Ralph Walkling. 1991. "A Test of the Free Cash Flow Hypothesis: The Case of Bidder Returns." Journal of Financial Economics 28:315-35.

Langlois, Richard N. 1992. "Transaction Cost Economics in Real Time." Industrial and Corporate Change 1:99-127.

—. 1994. "The Boundaries of the Firm." In The Elgar Companion to Austrian Economics. Peter J. Boettke, ed. Cheltenham, U.K.: Edward Elgar.

Lynch, Harry H. 1971. Financial Performance of Conglomerates. Boston: Harvard University Press.

Malkiel, Burton G. 1990. A Random Walk Down Wall Street. New York: W.W. Norton.

Manne, Henry G. 1965. "Mergers and the Market for Corporate Control." Journal of Political Economy 73 (April): 110-20.

Matsusaka, John G. 1993. "Takeover Motives during the Conglomerate Merger Wave." Rand Journal of Economics 24 (Autumn): 357-79.

- 2001. "Corporate Diversification, Value Maximization, and Organizational Capabilities." Journal of Business 74(3): 409-31,

Minkler, Alanson P. 1993. "The Problem with Dispersed Knowledge: Firms in Theory and Practice." Kyklos 46(4): 569-87.

Mises, Ludwig von. [1912] 1934. The Theory of Money and Credit. London: Jonathan Cape. 
[1920] 1990. Economic Calculation in the Socialist Commonwealth. Trans. S. Adler. Auburn, Ala.: Ludwig von Mises Institute.

— [1949] 1966. Human Action: A Treatise on Economics. 3rd Rev. Ed. Chicago: Henry Regnery.

— [1951] 1980. "Profit and Loss." In Planning for Freedom. 4th Ed. Spring Mills, Pa.: Libertarian Press. Pp. 108-50.

Mitchell, Mark L., and Kenneth Lehn. 1990. "Do Bad Bidders Become Good Targets?" Journal of Political Economy 98(2): 372-98.

Mitchell, Mark, and J. Harold Mulherin. 1996. "The Impact of Industry Shocks on Takeover and Restructuring Activity." Journal of Financial Economics 41 (June): 193-229.

Montgomery, Cynthia A., and Birger Wernerfelt. 1988. "Diversification, Ricardian Rents, and Tobin's q." Rand Journal of Economics 19(4): 623-32.

Morck, Randall, Andrei Shleifer, and Robert W. Vishny. 1988. "Management Ownership and Market Valuation: An Empirical Analysis." Journal of Financial Economics 20 (January-March): 293-315.

Mosakowski, Elaine. 1997. "Strategy Making Under Causal Ambiguity: Conceptual Issues and Empirical Evidence." Organization Science 8(4): 414-42.

Nelson, Richard R., and Sidney G. Winter. 1982. An Evolutionary Theory of Economic Change. Cambridge, Mass.: Harvard University Press.

Penrose, Edith. 1959. The Theory of the Growth of the Firm. New York: John Wiley and Sons.

Porter, Michael E. 1987. "From Competitive Advantage to Corporate Strategy." Harvard Business Review (May-June): 43-59.

Ravenscraft, David, and F.M. Scherer. 1987. Mergers, Sell-offs, and Economic Efficiency. Washington, D.C.: Brookings Institution.

—. 1991. "Divisional Sell-offs: A Hazard Function Analysis." Managerial and Decision Economics 12:429-38.

Roll, Richard. 1988. "Empirical Evidence on Takeover Activity and Shareholder Wealth." In Knights, Raiders, and Targets: the Impact of the Hostile Takeover. John C. Coffee, Jr., Louis Lowenstein, and Susan Rose-Ackerman, eds. New York: Oxford University Press. Pp. 241-52.

Rothbard, Murray N. [1962] 1993. Man, Economy, and State: A Treatise on Economic Principles. Auburn, Ala.: Ludwig von Mises Institute.

Rumelt, Richard P. 1974. Strategy, Structure and Economic Performance. Boston: Graduate School of Business Administration, Harvard University.

Rumelt, Richard P. 1982. "Diversification Strategy and Profitability." Strategic Management Journal 3 (October): 359-69.

Salerno, Joseph T. 1993. "Mises and Hayek Dehomogenized." Review of Austrian Economics 6(2): 113-46. 
Sanchez, Ron, Aimé Heene, and Howard Thomas. 1996. "Introduction: Towards the Theory and Practice of Competence-Based Competition." In Dynamics of Competence-Based Competition: Theory and Practice in the New Strategic Management. Sanchez, Heene, and Thomas, eds. London: Elsevier. Pp. 1-35.

Scharfstein, David. 1988. "The Disciplinary Role of Takeovers." Review of Economic Studies 55 (April): 185-99.

Servaes, Henri. 1996. "The Value of Diversification during the Conglomerate Merger Wave." Journal of Finance 51 (September): 1201-25.

Shleifer, Andrei, and Robert W. Vishny. 1989. "Management Entrenchment: The Case of Manager-Specific Investments." Journal of Financial Economics 25 (November): 123-39.

—. 1991. "Takeovers in the '60s and '80s: Evidence and Implications." Strategic Management Journal 12 (Winter): 51-59.

Schlingemann, Frederik P., René M. Stulz, and Ralph A. Walkling. 2000. "Asset Liquidity and Segment Divestitures." NBER Working Paper 7873.

Smith, Clifford W., Jr., and Ross L. Watts. 1992. "The Investment Opportunity Set and Corporate Financing, Dividend, and Compensation Policies." Journal of Financial Economics 32:263-92.

Spulber, Daniel F. 1992. "Economic Analysis and Management Strategy: A Survey." Journal of Economics and Management Strategy 1(3): 535-74.

Stein, Jeremy C. 1997. "Internal Capital Markets and the Competition for Corporate Resources." Journal of Finance 52(1): 111-33.

Wernerfelt, Birger. 1984. "A Resource-Based View of the Firm." Strategic Management Journal 5:171-80.

Weston, J. Fred. 1989. "Divestitures: Mistakes or Learning." Journal of Applied Corporate Finance 2:68-76.

Weston, J. Fred, Kwang S. Chung, and Susan E. Hoag. 1990. Mergers, Restructuring, and Corporate Control. Englewood Cliffs, N.J.: Prentice-Hall.

Williamson, Oliver E. 1975. Markets and Hierarchies: Analysis and Antitrust Implications. New York: Free Press. 